\title{
Badania wytrzymałości statycznej i zmęczeniowej ram wózków dwuosiowych wagonów towarowych zgodnie z przepisami UIC oraz TSI
}

\begin{abstract}
W artykule przedstawiono zagadnienia dotyczqce badań ram dwuosiowych wózków wagonów towarowych. Przedstawiono różnice jakie wprowadzily przepisy TSI w stosunku do przepisów UIC $w$ zakresie wymaganych sit oraz kryteriów oceny wytrzymałościowych badań stanowiskowych. Przedstawiono badania ramy wózka Y25Lsd1-K, którego uktad hamulcowy jest wyposażony we wstawki z tworzywa sztucznego tzw. wstawki typu K.
\end{abstract}

\section{Wstęp}

Rama wózka czteroosiowego wagonu towarowego na kolejach europejskich jest konstrukcją spawana. Najbardziej rozpowszechnionym wózkiem dwuosiowym jest wózek standardowy ERRI/UIC z zawieszeniem typu Y25. Pierwszym, który powstał $\mathrm{w}$ ramach prac standaryzacyjnych Grupy Roboczej B12.4, działającej na zlecenie ORE/ERRI był układ biegowy Y25Cs, który był dostosowany do nacisku zestawu kołowego na tor 20 ton oraz prędkości $100 \mathrm{~km} / \mathrm{h}$.

W wyniku dalszego rozwoju powstały standardowe wózki:

> wózek Y25Rss, przystosowany do nacisku zestawu kołowego na tor $20 \mathrm{t}$ oraz prędkości 120 $\mathrm{km} / \mathrm{h}$

> wózek Y25Lsd, przystosowany do nacisku zestawu kołowego na tor 22,5 t oraz prędkości 100 $\mathrm{km} / \mathrm{h}$ (z podłużnicami przyspawanymi do belki skrętowej oraz do czołownicy)

$>$ wózekY25Lsd1, przystosowany do nacisku zestawu kołowego na tor 22,5 t oraz prędkości 100 $\mathrm{km} / \mathrm{h}$ (z podłużnicami przykręcanymi do belki skrętowej)

$>$ wózki ww. typów typu Y25Lsd oraz Y25Lsd1, które w ramach zmniejszenia emisji hałasu do otoczenia są wyposażone we wstawki z tworzywa sztucznego typu K.

Grupa Robocza ORE/ERRI zakończyła swoją działalność w 1992 roku, ale ważne odmiany wózków wagonów towarowych powstały w oparciu o wózki standardowe, np. wózki Y25XL,Y25XXL, które są przystosowane do nacisku zestawu kołowego na tor, wynoszącego 25 ton i prędkości $100 \mathrm{~km} / \mathrm{h}$ oraz 30 ton i prędkości $80 \mathrm{~km} / \mathrm{h}$. Ponieważ pierwsze typy wózków standardowych powstawały w ramach prac Grupy Roboczej ORE/ERRI B12.4, pierwsze wytyczne do badań ram wózków zostały opracowane w ramach raportu ORE/ERRI B12/Rp.17 [3]. Następne wytyczne zostały sformułowane w karcie UIC 510-3 [2]. Wraz z wejściem w życie przepisów TSI dla wagonów towarowych, najnowsze wymagania zostały sformułowane w normie PN-EN 13749:2011[6].

\section{Wymagania konstrukcyjno-technologiczne dla wózka typu Y25}

Rama wózka typu Y25, wykonywana w wersji spawanej musi spełniać szereg wymagań konstrukcyjnotechnologicznych, a mianowicie:

$>$ warunek zamienności, przedstawiony $\mathrm{w}$ karcie UIC 510-1[1]

$>$ jakość spoin i procesu spawania oraz jego kontroli wg norm europejskich PN-EN

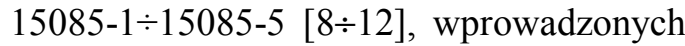
zamiast dotychczasowej karty UIC 897-13 [4]

$>$ nośność, która musi być wykazana badaniami stanowiskowymi, określonymi $\mathrm{w}$ normie europejskiej PN-EN 13749:2011[6]

$>$ zabezpieczenie antykorozyjne, którego celem jest zapewnienie między innymi własności wytrzymałościowych w trakcie przewidzianego okresu eksploatacji

$>$ płytki odporne na zużycie wg karty UIC 893 [3] kategorii E, przyspawane do lanych korpusów prowadnic

$>$ posiadać wsporniki, umożliwiające połączenie z innymi grupami konstrukcyjnymi do jakich można zaliczyć: zestawy kołowe wraz z maźnicami poprzez sprężyny zawieszenia pierwszego stopnia, hamulec-część mechaniczna lub/i cześć pneumatyczna, połączenie z nadwoziem (układ czopa skrętu oraz ślizgi boczne), uziemienie, zabezpieczenia zestawów kołowych przy podnosze- 
niu, zabezpieczenie trójkątów hamulcowych przed opadnięciem na tor.

Rama wózka stanowi zasadniczy zespół każdego wózka, złożony pod względem kształtu i wykonawstwa. Rama wózka towarowego musi przenosić podczas eksploatacji:

$>$ siły statyczne, mające charakter nadzwyczajny (ekstremalny)

$>$ siły zmęczeniowe, okresowo zmienne.

Rama jako ustrój nośny układu biegowego musi przenieść podczas eksploatacji następujące siły:

$>$ siły pionowe, przyłożone $\mathrm{w}$ gnieździe skrętu oraz w na ślizgach bocznych

$>$ siły wichrowania, przeniesione $\mathrm{z}$ toru wichrowatego przez koła na usprężynowanie pierwszego stopnia, a z niego na ramę

$>$ siły poprzeczne, pochodzące od przyspieszenia poprzecznego, działającego na pojazd

$>$ sily hamulcowe

$>$ siły rombowania.

Siły hamulcowe przenoszą się na badany wózek jako:

$>$ siły opóźnienia

$>$ siły nacisku wstawek klocków hamulcowych na koła

$>$ siły mocowania przekładni hamulcowej.

\subsection{Usuwanie naprężeń szczątkowych w spoinach}

\subsubsection{Uwagi ogólne}

Ponieważ pozytywny wynik badań wytrzymałościowych statycznych jest kryterium kwalifikującym ramę do dalszych badań, ważnym jest usunięcie naprężeń szczątkowych w konstrukcji spawanej ramy.

Można to zrobić, wykorzystując następujące metody:

$>$ metodą wyżarzania odprężającego zgodnie z kartą UIC 897-13 [4]

$>$ metodą odprężania wibracyjnego

$>$ metoda poddania ramy działania pionowej siły nadzwyczajnej przez okres 2 minut.

\subsubsection{Metoda odprężania wibracyjnego}

\subsubsection{Stan obiektu kierowanego do odprężania}

Odprężaniu należy poddać kompletną ramę wózka typu w stanie surowym, tzn. nieobrobioną mechanicznie, której spawanie wykonano zgodnie z wymaganiami dokumentacji konstrukcyjnej oraz Warunków Technicznych Wykonania i Odbioru Wózka. Zgodność ta powinna być potwierdzona dokumentem kontroli rodzaju $2.1 \mathrm{wg}$ normy PN-EN 10204 [5]. W przypadku stosowania czasowej ochrony antykorozyjnej należy uzgodnić z Wykonawcą odprężania pozostawienie lub usunięcie powłoki ochronnej.

\subsubsection{Cel do osiągnięcia}

Odprężanie ramy wózka ma na celu znaczącą redukcje naprężeń spawalniczych, dzięki czemu uzyskuje się:

- stabilizację wymiarową ramy, korzystną w aspekcie prawidłowego funkcjonowania wózka podczas eksploatacji

- podwyższenie trwałości eksploatacyjnej ramy.

\subsubsection{Metoda odprężania}

Zabiegowi odprężania podlega każda wyprodukowana rama. Metoda odprężania wibracyjnego jest uznawana jako najbardziej efektywna $\mathrm{z}$ wszystkich przedstawionych $\mathrm{w}$ p.2.1.1. Po przeprowadzeniu zabiegu odprężającego zabrania się wykonywania jakichkolwiek operacji cieplnych, przy czym w uzasadnionych przypadkach można odstapić od tej zasady po warunkiem uprzedniego uzyskania pisemnej zgody konstruktora ramy. Odprężanie wibracyjne powinno być wykonywane przez doświadczonego specjalistę, przy

użyciu aparatury i z zastosowaniem procedury gwarantujących osiagnięcie zamierzonego celu.

\subsubsection{Podstawy teoretyczne do stosowania meto- dy wibracyjnej}

Od wielu lat efektywnie stosowanym sposobem redukcji naprężeń resztkowych w wózkach pojazdów szynowych jest odprężanie wibracyjne, nazywane też stabilizacją wibracyjną. Mechanizm relaksacji naprężeń $\mathrm{w}$ elementach metalowych poddanych drganiom polega na tym, że w wyniku superpozycji naprężeń dynamicznych wprowadzonych przez drgania $\mathrm{z}$ naprężeniami resztkowymi, dochodzi w miejscach koncentracji naprężeń resztkowych do lokalnego osiagnięcia granicy plastyczności i lokalnych mikroodkształceń plastycznych powodujących rozładowanie tych naprężeń. Dużą rolę odgrywa tu tzw. efekt Bauschingera. Przejawia się on wyraźnym obniżeniem granicy plastyczności w przypadku następujących po sobie naprężeń o zmiennym znaku. Procesy te w niewielkim stopniu wpływają na zmianę ogólnego kształtu elementu, wprowadzaja go jednak w stan stabilny. Istotą odprężania wibracyjnego jest zatem doprowadzenie obrabianego elementu do odkształceń dynamicznych. Firma WIBROPOL stosuje w tym zakresie sposób, zwany odprężaniem

wibracyjnym rezonansowym, polegający na doprowadzaniu elementu do drgań rezonansowych, a więc takich, w których częstotliwość wibratora zgodna jest z częstotliwością drgań własnych elementu. 
Metoda wibracyjna ma wiele zalet w porównaniu $\mathrm{z}$ wyżarzaniem odprężającym:

$>$ może być stosowana na dowolnym etapie procesu technologicznego, np. tuż przed obróbką wykańczająca.

$>$ umożliwia stosowanie mniejszych naddatków technologicznych (brak zgorzeliny!).

$>$ umożliwia połączenie obróbki zgrubnej i półwykańczającej.

$>$ czas zabiegu ograniczony jest do kilkudziesięciu minut a nie kilkudziesięciu godzin,

$>$ jak to jest przy wyżarzaniu.

$>$ jest niezastapiona przy stabilizacji wymiarowej elementów regenerowanych np. przez spawanie lub napawanie.

$>$ nie pojawiają się żadne zmiany własności mechanicznych metali.

$>$ proces odprężania jest rejestrowany, a charakterystyki rezonansowe mogą służyć jako dokumenty w zakładowym systemie kontroli jakości.

Koszt samej procedury odprężania wibracyjnego

kształtuje się na poziomie ułamka kosztu

wyżarzania.

Poddawanie odprężaniu wibracyjnemu ram wózków wpływa też na zwiększanie ich wytrzymałości zmęczeniowej. Ma to wielkie znaczenie w sytuacji, gdy istotą pracy wózka jest przenoszenie dynamicznych obciążeń powstających w czasie jazdy.

\subsubsection{Oprzyrządowanie do stosowania metody wibracyjnej}

Aby zrealizować zadanie pobudzania do drgań rezonansowych elementów metalowych konieczne jest dysponowanie układem generującym siły okresowe o zmiennej częstotliwości. Ponieważ metale cechuje stosunkowo niewielkie thumienie materiałowe obszary rezonansów są stosunkowo wąskie. Wymaga to od układu wymuszającego wielkiej precyzji dopasowania częstotliwości siły wymuszającej do częstości rezonansowej elementu. Do kontrolowania tego procesu stosowne muszą być zaawansowane układy sterowania - odpowiednie do rodzaju napędu wibratora. Najczęściej używane $\mathrm{w}$ praktyce przemysłowej zestawy do odprężania wibracyjnego wykorzystuja jako źródło siły elektrowibratory z wirującą masą bezwładną. Są one źródłem wirującej siły dynamicznej.

Od zakresu obrotów wibratora zależy w znacznym stopniu doskonałość zestawu. Spotykane silniki elektrowibratorów zasilane prądem stałym sięgają z obrotami $80 \mathrm{~Hz}$, silniki na prąd przemienny mogą wirować zwykle z maksymalną częstotliwością $110 \mathrm{~Hz}$.

Kolejnym zadaniem procesu jest kontrola drgań elementu poddanego wymuszeniu. Służy do tego układ pomiaru przyspieszeń drgań. Mierzy on drgania reprezentatywne dla drgań całego elementu. Lokalizacja czujnika w pewnym stopniu decyduje o czułości i wrażliwości metody.

Poziom drgań rejestrowany jest w ciagu całego procesu w celu dokumentacji przebiegu procedury.

Analiza zarejestrowanych przebiegów pozwala też na ocenę efektywności odprężania.

Jak wynika z powyższego, kompletny zestaw do odprężania wibracyjnego składać się musi z następujących elementów:

$>$ sterownika zasilającego elektrowibrator

$>$ elektrowibratora przyczepnego

$>$ aparatury do pomiaru i rejestracji drgań.

Firma WIBROPOL stosuje przy odprężaniu wibracyjnym wózków profesjonalny zestaw VCM925 produkcji angielskiej. Zestaw ten cechuje się wszystkimi parametrami niezbędnymi do wykorzystywania go w różnorodnych zadaniach technologicznych, a więc zakresem częstotliwości $5 \div 220 \mathrm{~Hz}$, siłą odśrodkową do $18 \mathrm{kN}$ i odpornością na drgania przekraczająca $50 \mathrm{~g}=490,5 \mathrm{~m} / \mathrm{s}^{2}$. Te parametry są unikalne $\mathrm{w}$ skali światowej.

\subsubsection{Opis metodyki odprężania wibracyjnego}

Procedura odprężania składa się z kilku etapów. Ich właściwe przeprowadzenie warunkuje

osiagnięcie stanu stabilnego konstrukcji. Kolejne etapy polegają na:

$>$ przeprowadzeniu testu harmonicznego wibrowanego elementu w celu wyznaczenia jego charakterystyk rezonansowych; polega on na poddaniu konstrukcji drganiom o zmiennej częstotliwości i rejestrowaniu odpowiedzi, tzn. przyspieszeń drgań.

$>$ określenia postaci drgań własnych i rozkładu linii węzłowych

$>$ wyznaczeniu optymalnych punktów zamocowania wibratora i punktów podparcia wibrowanego elementu

$>$ wibrowaniu elementu na wybranych częstościach rezonansowych z obserwacją zachowania się elementu.

$>$ przeprowadzeniu, jeśli to konieczne ponownego testu harmonicznego dla określenia istotności zmian w rozkładzie częstości własnych spowodowanych redystrybucją naprężeń wewnętrznych.

Bardzo istotnym elementem metody jest ocena efektywności przeprowadzonej procedury.

Opiera się ona na obserwacji zjawisk zachodzących podczas wibrowania. Związane są one ze zmniejszeniem sztywności i thumienia materiałowego elementu w miarę usuwania naprężeń resztkowych. Te zmiany właściwości fizycznych wózka przejawiają się zmianami odpowiedzi dynamicznej na wymuszenie okresowe. 
Firmy wykonując odprężanie wibracyjne wózków pojazdów szynowych, muszą posiadać niezbędne doświadczenie w zakresie usuwania naprężeń szczątkowych z konstrukcji spawanych. Dzięki temu doświadczeniu możliwe jest właściwe przeprowadzenie każdego etapu procedury, która wymaga głębokiego rozumienia przez operatora dynamiki elementów ciągłych i aktywnego, prowadzonego w czasie wibrowania analizowania

zachodzących zjawisk. Taka analiza daje możliwość adaptacyjnego dochodzenia do właściwych rozwiązań. Rozpoczynając procedurę odprężania wibracyjnego, nie dysponuje się wiedzą jak ma ona przebiegać. Rozpoczynając procedurę odprężania wibracyjnego nie dysponuje się wiedzą, jak ona będzie przebiegać. Operator stabilizatora wibracyjnego musi być ekspertem w tej dziedzinie. Ta specyfika procesu nie pozwala niestety na sformułowanie ,receptury” prowadzenia odprężenia wibracyjnego. Od strony dynamicznej nie istnieją dwa identyczne elementy, a związku z tym nie istnieja dwie identyczne prowadzone procedury odprężania wibracyjnego. Każdorazowo konieczne jest prowadzenie aktywnej obserwacji zachodzących zjawisk i adaptacji metodyki do aktualnej sytuacji.

\subsubsection{Metoda przeprężania konstrukcji ramy}

Metoda ta polega obciążaniu każdej ramy siłą (dla wózków typu Y25L) ok.824 kN przez minimum dwie minuty. W trakcie obciążenia ramę należy opukiwać młotem przez blachę pośrednią, dokonując oględzin spoin lub młotem ołowianym tak, aby na ramie nie pozostały ślady młota po opukiwaniu. Punkty podparcia ramy oraz przyłożenia siły przeprężającej pokazano na rys.1.

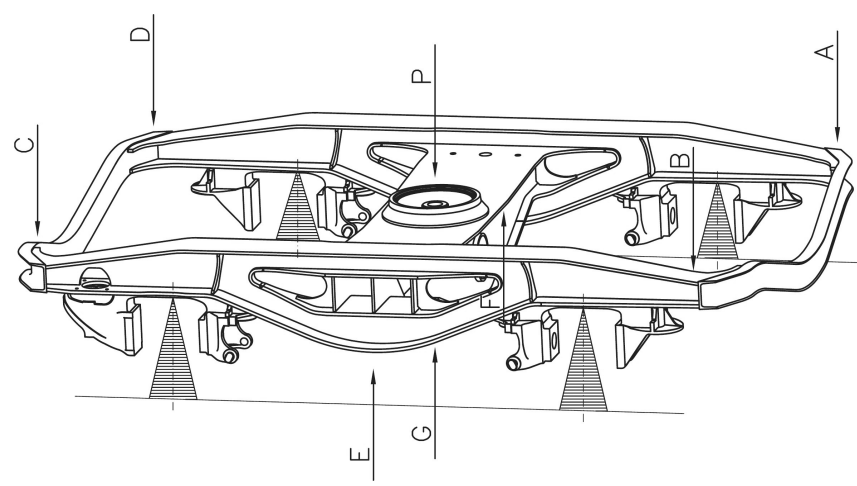

Rys.1. Obciążenie siłą przeprężającą P w celu usuwania naprężeń własnych

\section{Badania stanowiskowe wg przepisów UIC oraz normy europejskiej}

Badania stanowiskowe ramy wózka Y25 wg przepisów karty UIC 510-3[2] oraz PN-EN 13749:2011[6] są pod względem metodyki takie same. Istotne różnice wynikają z wartości niektórych sił oraz kryteriów oceny. Celem stanowiskowych badań wytrzymałościowych jest sprawdzenie poprawności zastosowanej technologii wytwarzania ramy i ich odbiorów technicznych, stosowanych przez producenta.

Badania stanowiskowe należy wykonać w następujących przypadkach:

$>$ w przypadku uruchomienia produkcji przez nowego producenta

$>\mathrm{w}$ przypadku zmiany technologii przez dotychczasowego producenta, o ile zmiany zastosowanej nowej technologii moga prowadzić do zmian wytrzymałości statycznej i zmęczeniowej

$>$ w przypadku zmian konstrukcyjnych, w tym stosowania materiałów o gorszych własnościach wytrzymałościowych niż są przewidziane w dokumentacji standardowej ORE/ERRI, lub do zastosowanych w pierwszych badaniach stanowiskowych, uprawniających do podjęcia produkcji ram wózków.

Badania stanowiskowe mają za zadanie symulowanie następujących przypadków eksploatacyjnych:

$>$ jazd wagonu towarowego na torze prostym

$>$ jazd wagonu towarowego w tuku

$>$ zmian sił spowodowanych przez kołysanie oraz pionową grę dynamiczną

$>$ hamowanie

$>$ przejazd wagonu towarowego przez tory wichrowate

Badania stanowiskowe można podzielić na:

$>$ badania statyczne na siły nadzwyczajne (niem. ,statische Versuche mit im Betrieb außergewöhnliche auftretenden Beanspruchungen" )

$>$ badania statyczne, celem symulacji sił dynamicznych występujących w eksploatacji (niem. „statischer Versuch zur Simulation der im Betrieb auftretenden dynamischen Kräfte")

$>$ badania dynamiczne (niem. „Dauerschwingversuch").

Stanowiskowe badania wytrzymałościowe są badaniami tensometrycznymi. Miejsce naklejenia tensometrów wynika z obliczeń wytrzymałościowych metoda elementów skończonych. Tensometry należy kleić $\mathrm{w}$ bliskim sąsiedztwie miejsc, w których metoda elementów skończonych wykazała duże wytężenie materiału. Tensometry powinny być naklejone we wszystkich „ćwiartkach” ramy wózka. Aby sprawdzić dokładność wskazań tensometrów należy kleić w sąsiedniej ćwiartce ramy wózka tzw. tensometry kontrolne.

Warunkiem przeprowadzania kolejnych etapów stanowiskowych prób wytrzymałościowych jest pozytywny wynik próby poprzedniej. Sposób klejenia tensometrów dla prób statycznych oraz prób dynamicznych ramy wózka jest przedstawiony na rys.2. 


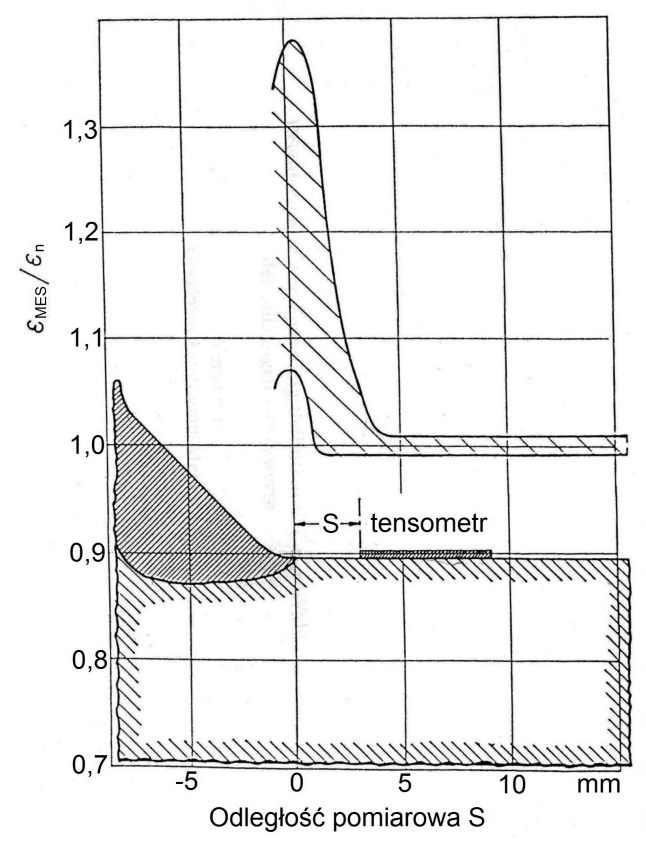

Rys.2. Sposób klejenia tensometrów na ramie wózka w sąsiedztwie karbu, jaki stanowi spoina Zależność miejsca klejenia tensometrów na ramie wózka od stosunku mierzonego odkształcenia

$\varepsilon_{\text {MES }}$ i obliczonego naprężenia nominalnego odkształcenia $\varepsilon_{n}$

Rys.2 przedstawia stosunek mierzonego odkształcenia $\varepsilon_{\mathrm{MES}}$ do obliczonego naprężenia nominalnego odkształcenia $\varepsilon_{n}$ dla różnych połączeń spawanych, które są przedstawione na rys.3. Założono, że tensometry są rozmieszczone w odległości $\geq 3 \mathrm{~mm}$ od początku spoin.
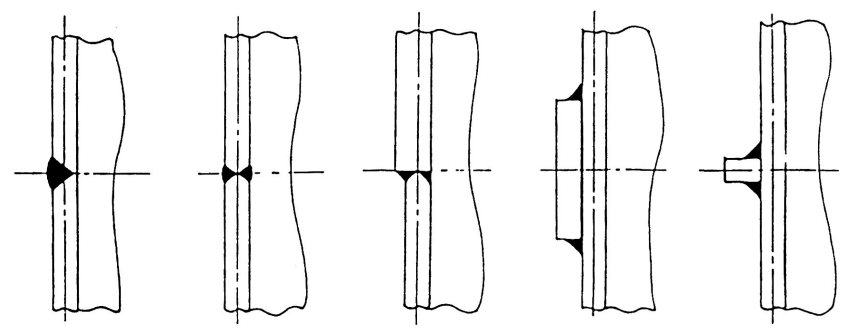

Rys.3. Rodzaje złącz spawanych z punktu widzenia lokalnego wytężenia materiału, gdzie koncentracja lokalna naprężeń odbywa się wg rys.2

\subsection{Badania stanowiskowe statyczne na obciążenia nadzwyczajne}

Kryterium badań statycznych na obciążenia nadzwyczajne, pojawiające się w eksploatacji jest brak odkształceń trwałych w konstrukcji. Brak odkształceń trwałych jest wynikiem naprężeń w poszczególnych miejscach, które nie przekraczaja granicy plastyczności materiałów użytych do wykonania ramy wózka.

Badania te polegają na superpozycji najbardziej niekorzystnych przypadków pojawiających się w eksploatacji. Obciążenia nadzwyczajne są przedstawione $\mathrm{w}$ tabeli 1. Obciążenia te są zgodne z kartą UIC 510-3 [2] oraz PN-EN 13349:2011 [6].
Kryterium badań statycznych na obciążenia występujące $w$ eksploatacji: naprężenia średnie, naprężenia maksymalne oraz amplituda naprężeń nie mogą przekraczać wartości dopuszczalnych, które można ustalić $\mathrm{z}$ wykresów Goodmana-Smitha. Wykresy te dla poszczególnych gatunków stali o różnej granicy wytrzymałości na rozciąganie oraz przypadków karbu są przedstawione w raporcie ORE/ERRI Rp.17. wydanie 9-te [13].

Amplitudę naprężeń można ustalić z następującego wzoru:

$$
\Delta \sigma=\frac{\sigma_{M A X}-\sigma_{M I N}}{2}
$$

gdzie:

$$
\begin{aligned}
& \sigma_{\mathrm{MAX}}=\text { maksymalne naprężenie cyklu } \\
& \sigma_{\mathrm{MIN}}=\text { minimalne naprężenie cyklu. }
\end{aligned}
$$

Naprężenie średnie ustala się ze wzoru:

$$
\sigma_{i r}=\frac{\sigma_{M A X}+\sigma_{M I N}}{2}
$$

Jeśli przyjąć współczynnik asymetrii cyklu R:

$$
R=\frac{\sigma_{M I N}}{\sigma_{M A X}}
$$

Wprowadzając wzór (3) do wzoru (1) otrzymuje się wzór na amplitudę naprężeń w cyklu badawczym:

$$
\Delta \sigma=\frac{\sigma_{M A X} \cdot(1-R)}{2}
$$

Wprowadzając wzór (3) do wzoru (2) otrzymuje się wzór na naprężenia średnie:

$$
\sigma_{s r}=\frac{\sigma_{M A X} \cdot(1+R)}{2}
$$

W ten sposób otrzymuje się zależność na amplitudę naprężeń:

$$
\Delta \sigma=\sigma_{s r} \cdot \frac{1-R}{1+R}
$$

Wartości sił nadzwyczajnych w statycznej próbie stanowiskowej wg wzorów, przytoczonych wg normy PN-EN 13749:2011 [6] oraz karty UIC 510-3 [2] sa podane w tabeli 1.

Siła $\mathrm{F}_{\mathrm{Z}^{-}}$jest siłą statyczną, natomiast siły definiowane przez współczynnik , $\alpha$ ” są siłami quasi-statycznymi, natomiast siły definiowane przez współczynnik , $\beta$ ” sa siłami dynamicznymi.

W przypadku normy PN-EN 13749:2011 [6] dochodzą siły rombujące (ang. „longitudinal lozenging forces”), które są przedstawione w tabeli 2. 
Tabela 1 Nadzwyczajne sily dzialające na ramę wózka w statycznej próbie stanowiskowej

\begin{tabular}{|c|c|c|c|c|c|c|c|}
\hline \multirow{2}{*}{$\begin{array}{l}\text { Przypadek } \\
\text { obciążenia }\end{array}$} & \multicolumn{3}{|c|}{ Sily pionowe } & \multirow{2}{*}{$\begin{array}{c}\text { Siła } \\
\text { poprzeczna } \\
F_{y}[\mathrm{kN}]\end{array}$} & \multirow{2}{*}{$\begin{array}{c}\text { Zwichrowanie } \\
g^{+}[\% / \mathrm{kN}]\end{array}$} & \multicolumn{2}{|c|}{ Sily hamowania } \\
\hline & $F_{z 2}[\mathrm{kN}]$ & $F_{z c}[\mathrm{kN}]$ & $F_{z 1}[\mathrm{kN}]$ & & & $F_{b z}[\mathrm{kN}]$ & $F_{b x}[\mathrm{kN}]$ \\
\hline \multirow{2}{*}{1} & \multirow{2}{*}{ - } & $2 F_{Z}$ & \multirow{2}{*}{ - } & \multirow{2}{*}{ - } & \multirow{2}{*}{ - } & \multirow{2}{*}{ - } & \multirow{2}{*}{ - } \\
\hline & & $794,9 \mathrm{kN}$ & & & & & \\
\hline \multirow{2}{*}{2} & \multirow{2}{*}{-} & $(1-\alpha) \cdot F_{z \max }$ & $\alpha \cdot F_{z \max }$ & \multirow{2}{*}{ - } & $+10 \%$ & \multirow{2}{*}{ - } & \multirow{2}{*}{-} \\
\hline & & $417,4 \mathrm{kN}$ & $178,9 \mathrm{kN}$ & & $15,6 \mathrm{kN}$ & & \\
\hline \multirow{2}{*}{3} & \multirow{2}{*}{ - } & $(1-\alpha) \cdot F_{z \max }$ & $\alpha \cdot F_{z \max }$ & \multirow{2}{*}{ - } & $-10 \%$ & \multirow{2}{*}{ - } & \multirow{2}{*}{ - } \\
\hline & & $417,4 \mathrm{kN}$ & $178,9 \mathrm{kN}$ & & $-15,6 k N$ & & \\
\hline \multirow{2}{*}{4} & $\alpha \cdot F_{\mathrm{zmax}}$ & $(1-\alpha) \cdot F_{z \max }$ & \multirow{2}{*}{ - } & \multirow{2}{*}{ - } & $+10 \%$ & \multirow{2}{*}{ - } & \multirow{2}{*}{ - } \\
\hline & $178,9 \mathrm{kN}$ & $417,4 \mathrm{kN}$ & & & $15,6 \mathrm{kN}$ & & \\
\hline \multirow{2}{*}{5} & $\alpha \cdot F_{\mathrm{zmax}}$ & $(1-\alpha) \cdot F_{z \max }$ & & \multirow{2}{*}{-} & $-10 \%$ & & \multirow{2}{*}{ - } \\
\hline & $178,9 \mathrm{kN}$ & $417,4 \mathrm{kN}$ & & & $-15,6 k N$ & & \\
\hline \multirow{2}{*}{6} & \multirow{2}{*}{ - } & $(1-\alpha) \cdot F_{z \max }$ & $\alpha \cdot F_{z \max }$ & $F_{y \max }$ & & & 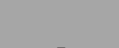 \\
\hline & & $417,4 \mathrm{kN}$ & $178,9 \mathrm{kN}$ & $167,2 \mathrm{kN}$ & & & 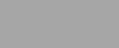 \\
\hline 7 & $\alpha \cdot F_{\mathrm{zmax}}$ & $(1-\alpha) \cdot F_{z \max }$ & & $-F_{y \max }$ & & & 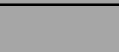 \\
\hline r & $178,9 \mathrm{kN}$ & $417,4 \mathrm{kN}$ & & $-167,2 k N$ & & & \\
\hline 8 & . & $1,2 \cdot F_{z}$ & 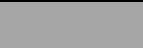 & 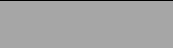 & 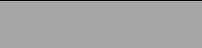 & $F_{b z \max }$ & $F_{b x \max }$ \\
\hline & & $477 k N$ & & & & $57,6 \mathrm{kN}$ & $7,2 \mathrm{kN}$ \\
\hline 0 & 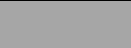 & $1,2 \cdot F_{z}$ & 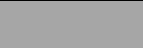 & 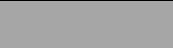 & 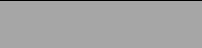 & $-F_{b z \max }$ & $-F_{b x \max }$ \\
\hline & & $477 k N$ & & & & $-57,6 k N$ & $-7,2 \mathrm{kN}$ \\
\hline
\end{tabular}

$\alpha$-współczynnik kotysania (niem. ,Wankkoeffizient”)

$\beta$ - wspótczynnik podskakiwania (niem. ,Tauchkoeffizient”)

Tabela 2 Nadzwyczajne siły rombujące wózek w statycznej próbie stanowiskowej

\begin{tabular}{|c|c|c|c|}
\hline \multirow{2}{*}{ L.p. } & $\begin{array}{c}\text { Sila pionowa przypadająca } \\
\text { na gniazdo skrętu }\end{array}$ & \multicolumn{2}{|c|}{ Sila wzdlużna rombująca przypadająca na: } \\
\cline { 2 - 4 } & {$[\mathbf{k N}]$} & Ostojnicę 1 & Ostojnicę 2 \\
\cline { 2 - 4 } & $\mathrm{F}_{\mathrm{Z}}$ & {$[\mathbf{k N}]$} & {$[\mathbf{k N ]}]$} \\
\hline \multirow{2}{*}{1} & 397,4 & 0 & 0 \\
\cline { 2 - 4 } & $\mathrm{F}_{\mathrm{Z}}$ & & $-\mathrm{F}_{\mathrm{x} 1}$ \\
\hline \multirow{2}{*}{2} & 397,4 & $\mathrm{~F}_{\mathrm{x} 1}$ & 44,15 \\
\hline \multirow{2}{*}{3} & $\mathrm{~F}_{\mathrm{Z}}$ & 44,15 & $\mathrm{~F}_{\mathrm{x} 1}$ \\
\hline & 397,4 & $-\mathrm{F}_{\mathrm{x} 1}$ & $-44,15$ \\
\hline
\end{tabular}

Jak widać z tabeli 1 przypadki obciążeń w większości stanowią kombinacje obciążeń, które mogą wystapić jednocześnie. Wtedy poszukiwanie maksymalnych naprężeń odbywa się drogą superpozycji najbardziej niekorzystnych przypadków i porównuje się z granicą plastyczności dla danego materiału. Norma PN-EN 13749:2011 [6] przyjmuje jako kryterium akceptacji w celu uniknięcia trwałego odkształcenia górna/umowną granicę plastyczności $R_{\mathrm{eH}}$ lub $\mathrm{R}_{\mathrm{p} 0,2}$ wg PN-EN ISO 6892-1:2010 [7] (jeśli $\mathrm{R}_{\mathrm{eH}}$ jest niedostępne to powinno 
zostać $\mathrm{R}_{\mathrm{p} 02}$ ). Ww. dokument dopuszcza lokalne obszary plastycznych odkształceń trwałych, pod warunkiem że funkcja struktury nie została pogorszona.

Tabela 3

Siły działające na ramę wózka w statycznej próbie stanowiskowej, symulującej siły występujące w eksploatacji

\subsection{Badania stanowiskowe statyczne na obciążenia występujące w eksploatacji}

Wartości sił wg PN-EN 13749:2011[6] oraz karty UIC 510-3 [2] W próbie stanowiskowej na obciążenia statyczne występujące $\mathrm{w}$ eksploatacji są podane w tabeli 3 .

\begin{tabular}{|c|c|c|c|c|c|c|c|}
\hline \multirow{2}{*}{$\begin{array}{l}\text { Przypadek } \\
\text { obciążenia }\end{array}$} & \multicolumn{3}{|c|}{ Sily pionowe } & \multirow{2}{*}{$\begin{array}{c}\begin{array}{c}\text { Sila } \\
\text { poprzeczna }\end{array} \\
F_{y}[\mathrm{kN}]\end{array}$} & \multirow{2}{*}{$\begin{array}{c}\text { Zwichrowanie } \\
g^{+}[\% / \mathbf{k N}]\end{array}$} & \multicolumn{2}{|c|}{$\begin{array}{c}\text { Sily } \\
\text { hamowania }\end{array}$} \\
\hline & $F_{z 2}[\mathbf{k} \mathbf{N}]$ & $F_{z c}[\mathbf{k N}]$ & $F_{z 1}[\mathbf{k N}]$ & & & $\begin{array}{c}F_{b z} \\
{[\mathbf{k N}]}\end{array}$ & $\begin{array}{c}F_{b x} \\
{[\mathbf{k N}]}\end{array}$ \\
\hline \multirow{2}{*}{1} & \multirow{2}{*}{-} & $F_{z}$ & \multirow{2}{*}{-} & \multirow{2}{*}{ - } & \multirow{2}{*}{-} & \multirow{2}{*}{-} & \multirow{2}{*}{ - } \\
\hline & & 397,5 & & & & & \\
\hline \multirow{2}{*}{2} & \multirow{2}{*}{ - } & $(1+\beta) F_{z}$ & \multirow{2}{*}{-} & \multirow{2}{*}{ - } & \multirow{2}{*}{ - } & \multirow{2}{*}{-} & \multirow{2}{*}{ - } \\
\hline & & 516,8 & & & & & \\
\hline \multirow{2}{*}{3} & \multirow{2}{*}{ - } & $(1-\beta) F_{z}$ & \multirow{2}{*}{-} & \multirow{2}{*}{ - } & \multirow{2}{*}{ - } & \multirow{2}{*}{-} & \multirow{2}{*}{-} \\
\hline & & 278,3 & & & & & \\
\hline \multirow{2}{*}{4} & - & $(1-\alpha)(1+\beta) F_{z}$ & $\alpha(1+\beta) F_{z}$ & $+\mathrm{F}_{\mathrm{y}}$ & - & - & - \\
\hline & 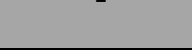 & 413,4 & 103,4 & 88,3 & - & - & - \\
\hline 5 & $\alpha(1+\beta) F_{z}$ & $(1-\alpha)(1+\beta) F_{z}$ & - & $-F_{y}$ & - & 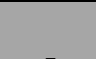 & 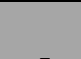 \\
\hline$J$ & 103,4 & 413,4 & - & $-88,3$ & - & - & - \\
\hline 6 & - & $(1-\alpha)(1+\beta) F_{z}$ & $\alpha(1+\beta) F_{z}$ & $+F_{y}$ & $+5 \%$ & - & - \\
\hline & - & 413,4 & 103,4 & 88,3 & $+7,8$ & - & \\
\hline 7 & 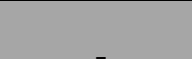 & $(1-\alpha)(1+\beta) F_{z}$ & $\alpha(1+\beta) F_{z}$ & $+F_{y}$ & $-5 \%$ & 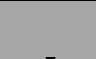 & 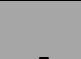 \\
\hline 1 & - & 413,4 & 103,4 & 88,3 & $-7,8$ & & - \\
\hline 8 & $\alpha(1+\beta) F_{z}$ & $(1-\alpha)(1+\beta) F_{z}$ & - & $-F_{y}$ & $+5 \%$ & - & - \\
\hline & 103,4 & 413,4 & & $-88,3$ & $+7,8$ & & \\
\hline 0 & $\alpha(1+\beta) F_{z}$ & $(1-\alpha)(1+\beta) F_{z}$ & 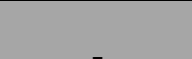 & $-F_{y}$ & $-5 \%$ & 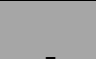 & 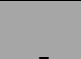 \\
\hline 9 & 103,4 & 413,4 & - & $-88,3$ & $-7,8$ & - & - \\
\hline 10 & - & $(1-\alpha)(1-\beta) F_{z}$ & $\alpha(1-\beta) F_{z}$ & $+F_{y}$ & - & - & - \\
\hline & & 222,6 & 55,7 & $+88,3$ & & & \\
\hline 11 & $\alpha(1-\beta) F_{z}$ & $(1-\alpha)(1-\beta) F_{z}$ & 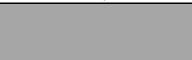 & $-F_{y}$ & & 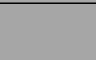 & 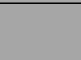 \\
\hline 11 & 55,7 & 222,6 & & $-88,3$ & 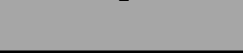 & & \\
\hline 12 & - & $(1-\alpha)(1-\beta) F_{z}$ & $\alpha(1-\beta) F_{z}$ & $+F_{y}$ & $+5 \%$ & & - \\
\hline & & 222,6 & 55,7 & $+88,3$ & $+7,8$ & & \\
\hline 13 & 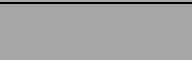 & $(1-\alpha)(1-\beta) F_{z}$ & $\alpha(1-\beta) F_{z}$ & $+F_{y}$ & $-5 \%$ & 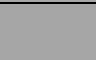 & 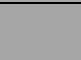 \\
\hline 15 & - & 222,6 & 55,7 & $+88,3$ & $-7,8$ & & \\
\hline 14 & $\alpha(1-\beta) F_{z}$ & $(1-\alpha)(1-\beta) F_{z}$ & - & $-F_{y}$ & $+5 \%$ & & _ \\
\hline & 55,7 & 222,6 & & $-88,3$ & $+7,8$ & & \\
\hline 15 & $\alpha(1-\beta) F_{z}$ & $(1-\alpha)(1-\beta) F_{z}$ & 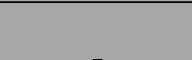 & $-F_{y}$ & $-5 \%$ & - & 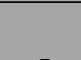 \\
\hline 10 & 55,7 & 222,6 & - & $-88,3$ & $-7,8$ & - & - \\
\hline 16 & - & $\bar{F}$ & & 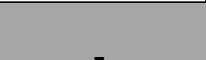 & & $F_{b z}$ & $F_{b x}$ \\
\hline 10 & & 397,5 & & & & 6 & 48 \\
\hline 17 & - & $F_{z}$ & - & - & - & $-F_{b Z}$ & $-F_{b x}$ \\
\hline & & 397,5 & & & & -6 & -48 \\
\hline
\end{tabular}


Próba stanowiskowa z obciążeniami statycznymi, symulująca obciążenia występujące $\mathrm{w}$ eksploatacji jest przeprowadzona przed testem dynamicznym. Celem tej próby jest zbadanie, czy naprężenia w przypadku przykładanych obciążeń lub ich kombinacji nie przekraczają naprężeń dopuszczalnych, określonych na podstawie wykresów Goodmana-Smitha. Wykresy Goodmna-Smitha są ustalane w laboratoriach badawczych na podstawie prób rozciagania, ściskania i zginania na próbkach. W przypadku zastosowania rozet tensometrycznych ustala się naprężenia główne, które porównuje się z naprężeniami dopuszczalnymi z wykresu Goodmana-Smitha. Pozytywny wynik badań statycznych z siłami występującymi w eksploatacji jest warunkiem rozpoczęcia testu dynamicznego.

\subsection{Stanowiskowe badania dynamiczne}

Stanowisko do badań dynamicznych jest przedstawione na rys. 4 .

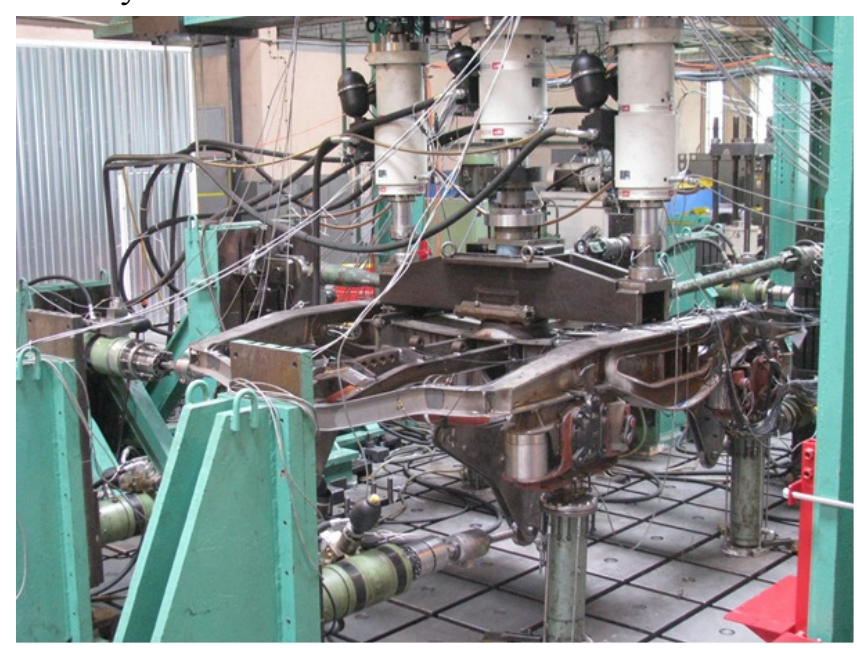

Rys.4.Stanowisko do badań zmęczeniowych-rama wózka typu Y25

Badania zmęczeniowe (dynamiczne) ramy wózka na stanowisku próbnym.

W próbie reprezentowane są:

$>$ obciążenia pionowe na gniazdo skrętu i na ślizgach bocznych,

$>$ siły poprzeczne,

$>$ siły wynikające $\mathrm{z}$ wichrowatego toru,

$>$ siły wynikające $\mathrm{z}$ hamowania.

W próbie zmęczeniowej nie uwzględnia się sił hamulcowych, jeśli nie zostanie stwierdzone przekroczenie granicy plastyczności materiału ramy w mierzonych punktach pomiaru naprężeń podczas wykonywania statycznych prób wytrzymałościowych na obciążenia nadzwyczajne.

Przebieg badań zmęczeniowych zgodnie z PN-EN 13749:2011 [6].

Badania wykonuje się pod obciążeniami, których wielkość i przebieg pokazano na rys. 5. Obciążenia obliczono wg następujących zależności dla poszczególnych stopni obciążeń:

I - stopień obciążenia:

$$
\begin{aligned}
F_{z} & =4 Q_{0}-m^{+} \cdot g \\
\alpha & =0,2 \\
\beta & =0,3
\end{aligned}
$$

Siła działająca na ślizgi boczne:

$$
F_{z 1}=F_{z 2}=\alpha \cdot F_{z} \pm \beta \cdot \alpha \cdot F_{z}
$$

Siła poprzeczna:

$$
F_{y}= \pm 0,1 \cdot\left(F_{z}+m^{+} \cdot g\right) \pm 0,1 \cdot\left(F_{z}+m^{+} \cdot g\right)
$$

II - stopień obciążenia:

$$
\begin{gathered}
F_{z}=4 Q_{0}-m^{+} \cdot g \\
\alpha=0,2 \\
\beta=0,3
\end{gathered}
$$

Siła działająca na czop skrętu:

$$
F_{z c}=(1-1,2 \alpha) \cdot F_{z} \pm 1,2 \beta \cdot(1-1,2 \alpha) F_{z}
$$

Siła działająca na ślizg boczny:

$$
F_{z 1}=F_{z 2}=1,2 \alpha \cdot F_{z} \pm 1,2 \beta \cdot 1,2 \alpha \cdot F_{z}
$$

Siła poprzeczna:

$$
F_{y}= \pm 1,2 \cdot 0,1 \cdot\left(F_{z}+m^{+} \cdot g\right) \pm 1,2 \cdot 0,1 \cdot\left(F_{z}+m^{+} \cdot g\right)
$$

III - stopień obciążenia:

Siła działająca na czop skrętu:

$$
\begin{gathered}
F_{z}=4 Q_{0}-m^{+} \cdot g \\
\alpha=0,2 \\
\beta=0,3
\end{gathered}
$$

Siła działająca na czop skrętu:

$$
F_{z c}=(1-1,4 \alpha) \cdot F_{z} \pm 1,4 \beta \cdot(1-1,4 \alpha) F_{z}
$$

Siła działająca na ślizgi boczne:

$$
F_{z 1}=F_{z 2}=1,4 \alpha \cdot F_{z} \pm 1,4 \beta \cdot 1,4 \alpha \cdot F_{z}
$$

Siła poprzeczna:

$$
F_{y}= \pm 1,4 \cdot 0,1 \cdot\left(F_{z}+m^{+} \cdot g\right) \pm 1,4 \cdot 0,1 \cdot\left(F_{z}+m^{+} g\right)
$$

W czasie próby mierzy się naprężenia maksymalne przed rozpoczęciem próby oraz kilka razy (ilość ustali wykonawca) w czasie próby $\mathrm{w}$ celu kontroli niezmienności obciążeń oraz w celu wykrycia węzłów, które tracą nośność na skutek uszkodzenia nie wykrytego innym sposobem.

Tensometry rozmieszcza się tylko w punktach szczególnie obciążonych, ustalonych $\mathrm{w}$ czasie próby statycznej. W czasie próby tyle samo razy symuluje się jazdę w lewym co w prawym łuku toru. Całkowita liczba cykli w 1 - szym stopniu obciążeń wynosi $6 \cdot 10^{6}$ cykli. 
Drugi stopień obciążenia $\mathrm{w}$ zakresie $(6 \div 8) \cdot 10^{6}$ cykli wykonuje się przy niezmienionych obciążeniach statycznych, natomiast siły quasistatyczne i dynamiczne zwiększa się o współczynnik 1,2.

W końcu następuje trzeci stopień obciążenia w zakresie $(8 \div 10) \cdot 10^{6}$ cykli gdzie współczynnik zwiększający siły quasistatyczne i dynamiczne wynosi $1,4 \mathrm{w}$ stosunku do obciążeń z 1 - szego stopnia obciążenia.

\section{Obciążenia wichrujące.}

W 1- szym stopniu obciążeń realizuje się $6 \cdot 10^{5}$ cykli obciążeń wichrujących.

W następnych 2 - ch stopniach obciążeń realizuje się po $2 \cdot 10^{5}$ cykli obciążeń wichrujących i również za każdym razem połowę w jedną a połowę w 2 - gą stronę.

Jeśli w próbie 4.3 okazałoby się, że rama nie reaguje na wichrowatość 5\%. to w próbie zmęczeniowej można pominąć obciążenia wichrujące - co jest zgodne $\mathrm{z}$ kartą UIC 510-3 [2].

Przebiegi sił w I,II i III stopniu obciążenia podczas testu dynamicznego sa przedstawione na rys.5 na rys.6.

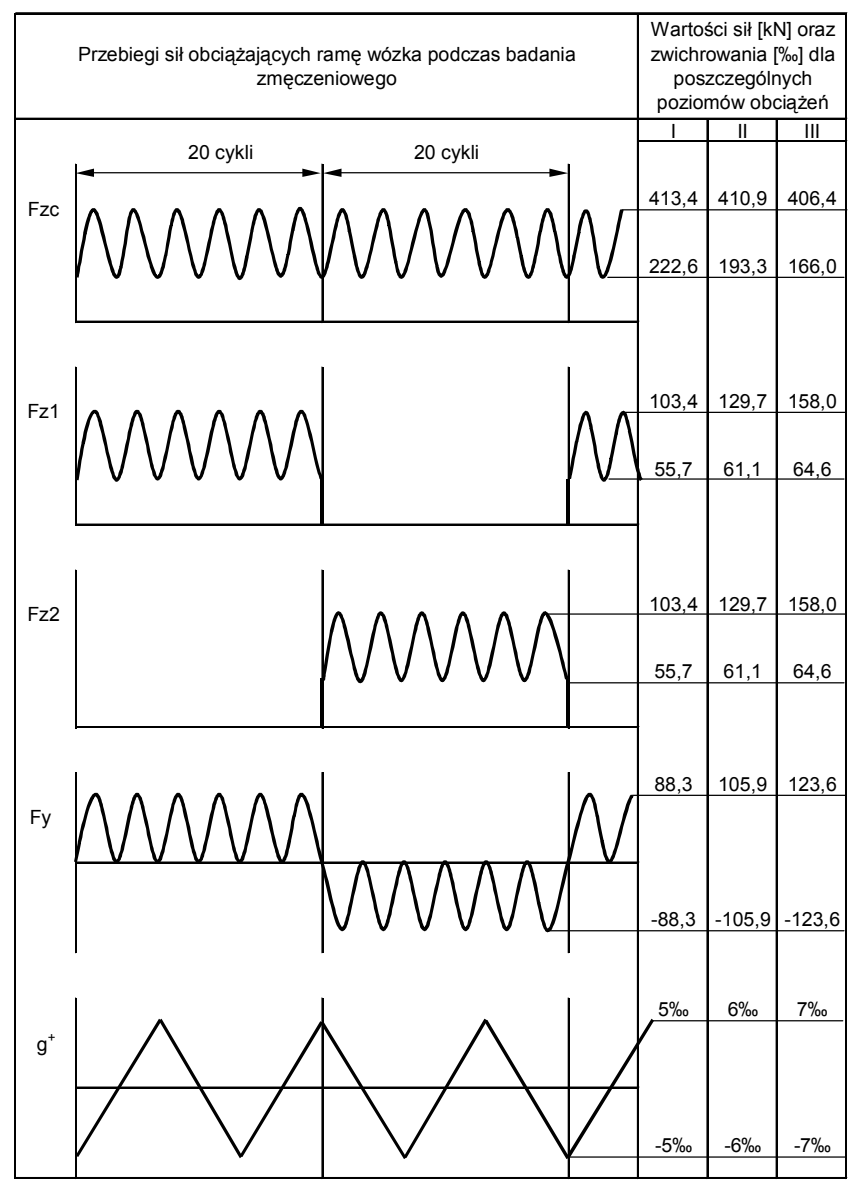

Rys.5. Przebiegi sił oraz ich wartości dla poszczególnych poziomów obciążeń

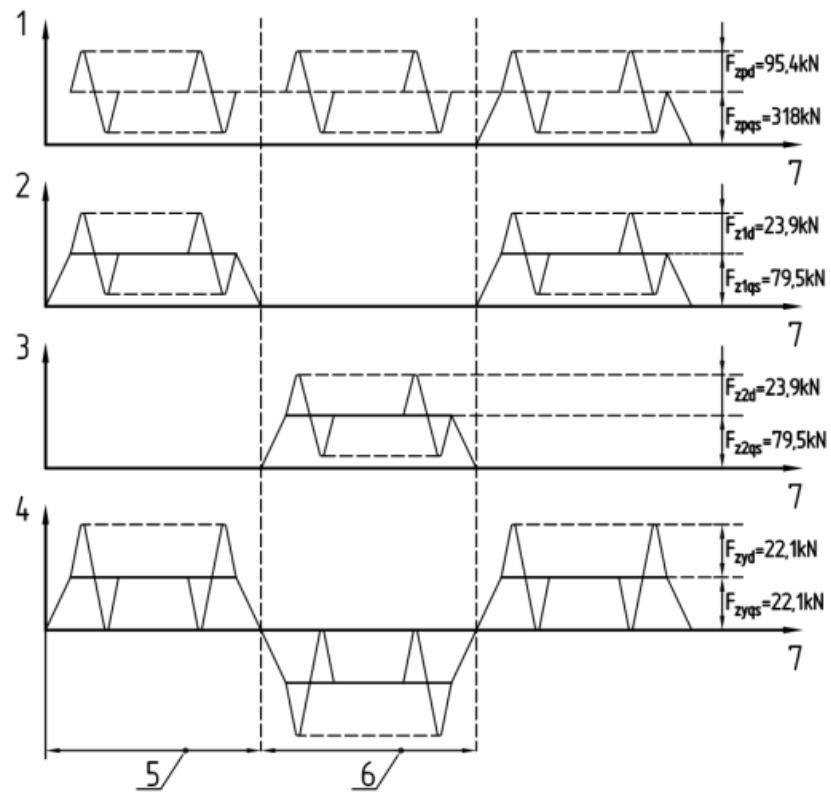

Legenda:

1- siła przyłożona do czopa skrętu $\mathrm{F}_{\mathrm{ZP}}$

3-siła przyłożona do ślizgu bocznego $1, \mathrm{~F}_{\mathrm{Z} 2}$

5-łuk prawy, n-cykli

2-siła przyłożona do ślizgu bocznego $\mathrm{F}_{\mathrm{z} 1}$

4-siła poprzeczna

6-łuk lewy, n-cykli

$\mathrm{F}_{\mathrm{zzqs}}$ - pionowa siła quasistatyczna, 2-gi ślizg boczny

$\mathrm{F}_{\text {yqs }}$ poprzeczna siła quasistatyczna, przyłożona na każdą oś

$\mathrm{F}_{\text {zpd }}$ pionowa siła dynamiczna, działająca na czop skrętu

$\mathrm{F}_{\mathrm{zld}} \mathrm{d}^{-}$pionowa siła dynamiczna,1-szy ślizg boczny

$\mathrm{F}_{\mathrm{z2d}}$-pionowa siła dynamiczna, 2-gi ślizg boczny

$\mathrm{F}_{\mathrm{yd}^{-}}$poprzeczna siła quasistatyczna, przyłożo-na na każdą oś

Rys.6. Przebiegi sił pionowych oraz sił poprzecznych w odniesieniu do czasu w I stopniu obciążenia zgodnie z EN 13749:2011 i kartą UIC 510-3

Uwaga: Do obciążeń pionowych oraz poprzecznych należy dodać obciążenia wichrujące zgodnie $\mathrm{z}$ rys. 1

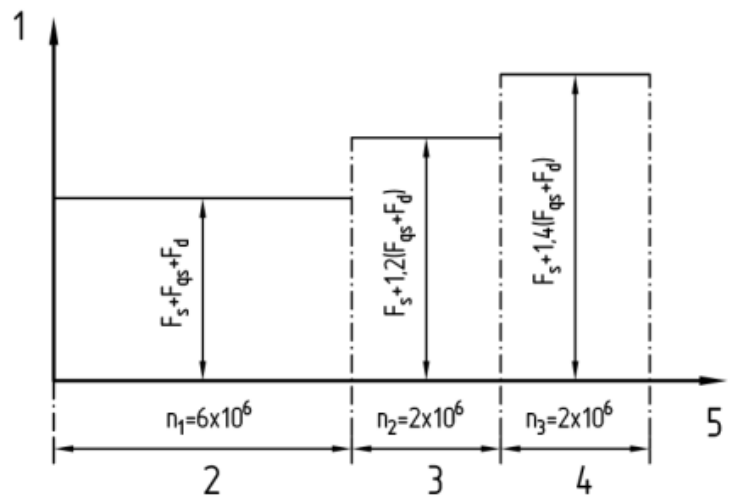

Key

1 force magnitude $\quad 21^{\text {st }}$ load sequence

$32^{\text {nd }}$ load sequence $\quad 43^{\text {rd }}$ load sequence

5 cycles

Rys.7. Pierwszy, drugi i trzeci stopień obciążenia ramy podczas badań zmęczeniowych ramy wózka 
Istotnym kryterium badań zmęczeniowych jest brak pęknięć zmęczeniowych. Idealnym przypadkiem, nie budzącym wątpliwości byłby brak pęknięć zmęczeniowych po przeprowadzonych III cyklach obciążeń. Kontrolę występowania ewentualnych pęknięć zmęczeniowych należy przeprowadzać po 1 milionie cykli podczas wszystkich trzech stopni obciążeń. Należy sprawdzać również poziom naprężeń w tensometrach. Każdy spadek naprężen, mierzonych przez poszczególne tensometry $\mathrm{W}$ stosunku do wcześniej zmierzonych może świadczyć o braku ciągłości materiału. Przykłady pęknięć zmęczeniowych, które wystapiły podczas badan ram wózków typu Y25 są przedstawione na rys. 8 i 9.

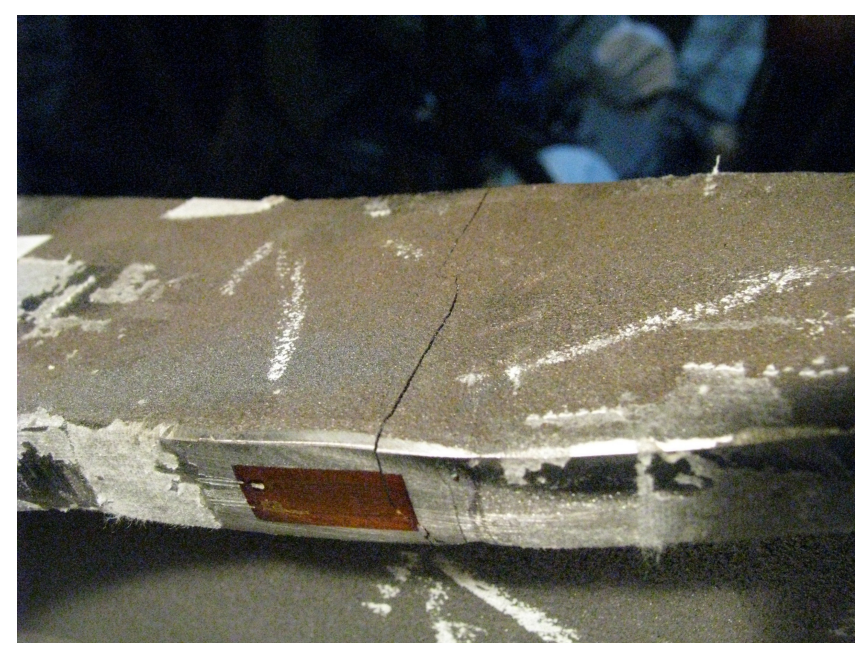

Rys.8. Pęknięcie zmęczeniowe w oknie ostojnicy

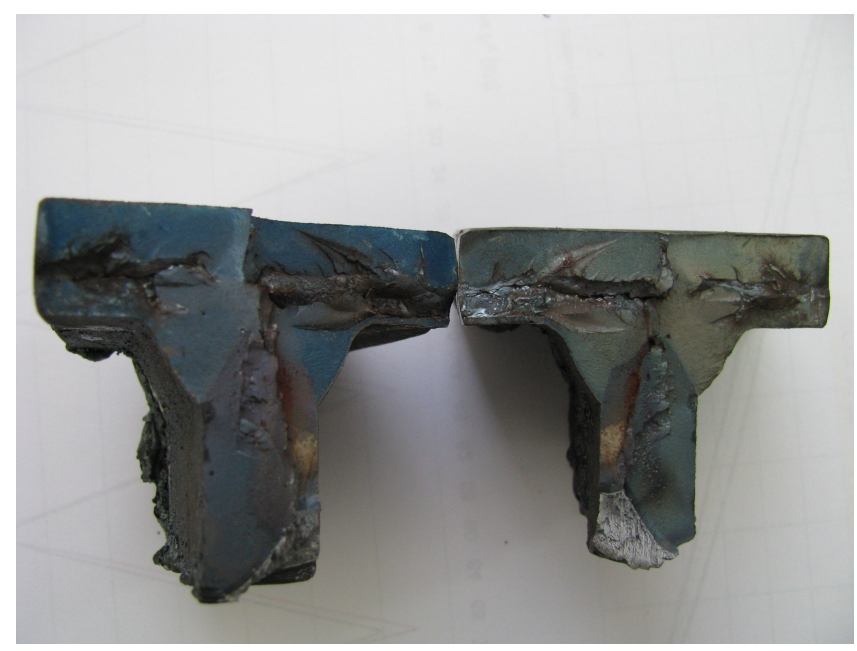

Rys.9. Fragmenty przełomów zmęczeniowych ramy wózka Y25

\section{Porównanie normy PN-EN 13749:2011 i karty UIC 510-3}

Norma europejska PN-EN 13749:2011 [6] dzieli wózki na siedem kategorii:

$>$ kategoria B-I: wózki dla pojazdów pasażerskich liniowych oraz kategorii inter-city, włączając $w$ to pojazdy oraz bardzo dużych prędkości, trakcyjne lub toczne
> kategoria B-II: wózki dla pojazdów pasażerskich podmiejskich, trakcyjne lub toczne

> kategoria B-III: wózki dla pojazdów metra oraz szybkiej kolei miejskiej, trakcyjne lub toczne

> kategoria B-IV: wózki dla pojazdów szynowych oraz tramwajów

> kategoria B-V: wózki dla wagonów towarowych z jednostopniowym usprężynowaniem

$>$ kategoria B-VI: wózki dla taboru szynowego $\mathrm{z}$ dwustopniowym usprężynowaniem

$>$ kategoria B-VII: wózki dla lokomotyw.

Jak widać norma PN-EN 13749:2011 [6] obejmuje stanowiskowe badania wytrzymałościowe wszystkich pojazdów, natomiast karta UIC 510-3 [2] obejmuje badania ram wózków towarowych dwuosiowych lub sześcioosiowych.

Norma PN-EN 13749:2011 [6] wprowadza dodatkowo siły rombujące ramę wózka, co jest dokładnie przedstawione w tabeli 2 . Siły te należy wprowadzić w badaniach stanowiskowych na obciążenia nadzwyczajne. Karta UIC 510-3 [2] koncentruje się szczegółowo na technice przeprowadzenia badań zmęczeniowych. Kontrolę pęknięć zmęczeniowych należy przeprowadzać przynajmniej raz na $1 \times 10^{6}$ cykli obciążeń posługując się metodą penetracyjną lub magnetycznoproszkową. Najistotniejsza różnica jest jednak w kryteriach badań zmęczeniowych. W karcie UIC 510-3 [2] w p.4.3.1 znajduje się następujące zdanie: „Po zakończeniu drugiego stopnia obciążeń są dopuszczalne tylko małe rysy, które gdyby powstały w eksploatacji nie wymagałyby natychmiastowej naprawy." W normie PN-EN 13749:2011 [6] w punkcie G.2 jest zapis następujący: „Rama wózka może być uznana za wystarczająco wytrzymałą jeżeli spełnia oba poniższe warunki:

$>$ żadne pęknięcia nie ujawniły się na zakończenie I i II etapu

$>$ dopuszcza się występowanie bardzo małych pęknięć podczas III etapu, jeżeli pojawiają się w trakcie badań i nie wymagają natychmiastowej naprawy."

Tak więc norma PN-EN 13749:2011[6] formułuje ostrzejsze wymagania dotyczące powstawania pęknięć zmęczeniowych $\mathrm{w}$ teście dynamicznym ram wózków wagonów towarowych, co może być interpretowane jako zamiar zwiększenia bezpieczeństwa kursującego taboru. W przypadku karty UIC 510-3 [2] w p.3.3. występuje zapis dotyczący przebiegu badań dynamicznych. O brzmieniu następującym: „Na każdym miejscu pomiarowym muszą występować dopuszczalne naprężenia, które są podane na diagramach wytrzymałości zmęczeniowej w raporcie ORE/ERRI B12 Rp.17 [13]. Na ograniczonej ilości miejsc pomiarowych, na które należy zwrócić szczególną uwagę przy prowadzeniu testu zmęczeniowego, ze dopuszczalne są przekroczenia dopuszczalnych naprężeń o $20 \%$.(1)" 
i dalej w przypisie (1) „Jeśli w trakcie testu zmęczeniowego w I stopniu obciążeń nie pojawiły się żadne rysy, można zaakceptować naprężenia w próbach statycznych i dopuścić ramę wózka.

\section{WNIOSKI}

1. Jak wynika $z$ przeprowadzonego porównania w przypadku badań ram wózków należy przestrzegać przepisów TSI „Wagony towarowe” [14], aby zapewnić warunek interoperacyjności jako podstawowy warunek ruchu transgranicznego wagonów towarowych wózkowych.

2. Przepisy TSI ,Wagony towarowe”, przywołują normę europejską PN-EN 13749:2011 [6], definiująca test statyczny oraz test zmęczeniowy.

Norma ta jest oparta o kartę UIC 510-3 [2], ale wykazuje pewne różnice, które należy bezwzględnie wziąć pod uwage przy opracowaniu programów prób i badań $\mathrm{i}$ raportów $\mathrm{z}$ ich przeprowadzenia.

3. W programie można uwzględnić pewne zapisy z karty UIC 510-3, jednakże nie mogą one dotyczyć rodzaju sił, ich wielkości oraz kryteriów oceny.

\section{LITERATURA}

[1] Karta UIC 510-1: Wagony towarowe. Uktad biegowy-Normalizacja.

[2] Karta UIC 510-3: Wagony towarowe. Badania stanowiskowe ram 2 i 3 osiowych wózków wagonów towarowych. 4-te wydanie z października 2002 i kwietnia 2004.

[3] Karta UIC 893: Warunki prowadnicowe dla dostawy blach na plyty prowadnicowe ze stali manganowej. 2-gie wydanie z czerwca 2004.

[4] Karta UIC 897-13: Warunki techniczne dla kontroli jakości złacz spawanych części pojazdów ze stali. Wydanie 2 ze stycznia 1993.

[5] PN-EN 10204: Wyroby metalowe. Rodzaje dokumentów kontroli.

[6] PN-EN 13749:2011: Kolejnictwo. Zestawy kołowe $i$ wózki. Metody określania wymagań konstrukcyjnych dla ram wózków.

[7] PN-EN ISO 6892-1:2010: Metale. Próba rozciqgania. Część 1:Metoda badania w temperaturze pokojowej.

[8] PN-EN 15085-1:2007: Kolejnictwo. Spawanie pojazdów szynowych $i$ ich części składowych część 1:Postanowienia ogólne

[9] PN-EN 15085-2:2007: Kolejnictwo. Spawanie pojazdów szynowych i ich części skladowych-część 2:Wymagania dotyczace jakości i certyfikacja zakładów spawalniczych.

[10] PN-EN 15085-3:2007: Kolejnictwo. Spawanie pojazdów szynowych i ich części sktadowych-część 3: Wymagania konstrukcyjne.

[11] PN-EN 15085-4:2007: Kolejnictwo. Spawanie pojazdów szynowych i ich części sktadowe-część 4:Wymagania produkcyjne.

[12] PN-EN 15085-5:2007: Kolejnictwo. Spawanie pojazdów szynowych $i$ ich części składowych część 5: Kontrola, badania i dokumentacja.

[13] Raport ORE/ERRI B12 Rp.17.Wydanie 8: Program prób dla wagonów z podwoziem i struktura wagonu ze stali, nadajacych się do zabudowy automatycznego sprzegu ciegtowo-zderznego oraz wózków z ramq stalowq." Utrecht, lipiec 2012

[14] TSI „Wagony towarowe” dodatek D, dokument $n r C$ (2006), 3345, obowiqzuje od 1.01.2014 Dz.U.UE $n r 104$ z 12.04.2013 